\title{
Kajian Penyempurnaan Kurikulum Program Studi Ilmu Komunikasi Universitas Terbuka Dari Sudut Pandang Alumni dan Pengguna Lulusan
}

\author{
Ida Royandiah ${ }^{1 \star}$, Gunawan Wiradharma ${ }^{2}$, Isma Dwi Fiani ${ }^{3}$, Arifah Bintarti $^{4}$, \\ Nila Kusuma Windrati ${ }^{5}$ \\ 1,2,3,4,5 Program Studi Ilmu Komunikasi, Fakultas Hukum, Ilmu Sosial, dan Ilmu Politik, \\ Universitas Terbuka \\ e-mail: idar@ecampus.ut.ac.id
}

\begin{tabular}{|c|c|}
\hline Article Info & Abstract \\
\hline $\begin{array}{l}\text { Article history: } \\
\text { Received } \\
\text { July } 21^{\text {th }}, 2021 \\
\text { Revised } \\
\text { November } 30^{\text {th }}, 2021 \\
\text { Accepted } \\
\text { December } 4^{\text {th }}, 2021 \\
\text { Published } \\
\text { December } 5^{\text {th }}, 2021\end{array}$ & $\begin{array}{l}\text { The educational program offered by UT must be able to accommodate the demands } \\
\text { of students for the competencies and skills they expect they will acquire from their } \\
\text { study process by the objectives set by the study program and can meet market needs. } \\
\text { Measurement of the performance of graduates of a study program can be done } \\
\text { through a tracer study. Feedback obtained from graduates of a study program is } \\
\text { needed by universities to improve service quality and program implementation. } \\
\text { Feedback is also useful for universities to map the world of business and indus- } \\
\text { try so that the gap between the competencies obtained by alumni during college } \\
\text { and the demands of the world of work can be minimized. The UPBJJ-UT locations } \\
\text { used as research locations consisted of Surakarta, Jakarta, Mataram, Banda Aceh, } \\
\text { Malang, Yogyakarta, Bandung, Purwokerto, and Bogor. The results of this study } \\
\text { provide information about the competency profile of graduates and graduate users } \\
\text { from institutions. In addition, graduate tracking research is the basis for evaluating } \\
\text { the curriculum of an educational program to show the strengths and weaknesses } \\
\text { of the curriculum to produce suggestions for basic improvements are linked to the } \\
\text { "Kampus Merdeka" policy. }\end{array}$ \\
\hline
\end{tabular}

Keywords: communication science study program, graduate tracking, curriculum, alumni, graduate users, kampus merdeka

\begin{abstract}
Abstrak
$\overline{\text { Program pendidikan yang ditawarkan UT harus dapat mengakomodasi tuntutan }}$ peserta didik akan kompetensi dan keterampilan yang mereka harapkan akan mereka peroleh dari proses studi mereka sesuai dengan tujuan yang telah ditetapkan program studi, serta dapat memenuhi kebutuhan pasar. Pengukuran terhadap kinerja lulusan suatu program studi dapat dilakukan melalui tracer study (penelusuran lulusan). Umpan balik yang diperoleh dari lulusan suatu program studi sangat dibutuhkan oleh perguruan tinggi untuk memperbaiki kualitas layanan dan pelaksanaan program yang diselenggarakan. Umpan balik ini juga bermanfaat pula bagi perguruan tinggi untuk memetakan dunia usaha dan industri agar jeda diantara kompetensi yang diperoleh alumni saat kuliah dengan tuntutan dunia kerja dapat diperkecil. Lokasi UPBJJ-UT yang dijadikan sebagai lokasi penelitian terdiri atas Surakarta, Jakarta, Mataram, Banda Aceh, Malang, Yogyakarta, Bandung, Purwokerto, dan Bogor. Hasil penelitian ini memberikan informasi tentang profil kompetensi lulusan dan pengguna lulusan dari instansiinstansi. Selain itu, penelitian penelusuran lulusan dijadikan dasar untuk mengevaluasi kurikulum suatu program pendidikan untuk menunjukkan kelebihan dan kelemahan kurikulum sehingga menghasilkan saran perbaikan yang mendasar dan dikaitkan dengan kebijakan "kampus merdeka".
\end{abstract}

Kata Kunci: program studi ilmu komunikasi; penelusuran lulusan; kurikulum; alumni; pengguna lulusan; kampus merdeka 
Ida Royandiah dkk, TitleKajian Penyempurnaan Kurikulum Program Studi Ilmu Komunikasi Universitas ...

\section{PENDAHULUAN}

Program Kampus Merdeka yang diluncurkan oleh Kementerian Pendidikan dan Kebudayaan (Mendikbud) pada akhir tahun 2020 menjadi sebuah program ini bertujuan untuk mengembangkan pendidikan tinggi agar proses pembelajaran dapat beradaptasi dengan kemajuan zaman, sejalan dengan Peraturan Kementerian Pendidikan dan Kebudayaan Nomor 22 Tahun 2020 untuk Tahun 2020- Rencana Strategis 2024 (Putra et al.,2021; Sihombing et al.,2021). Tujuan program ditetapkan sesuai dengan delapan indikator kinerja utama (KPI) yang ditetapkan dalam Peraturan Menteri No. 754/P/2020. Program Kampus Mandiri berupaya untuk meningkatkan kapasitas serta kualitas pendidikan di perguruan tinggi Indonesia. Sektor pendidikan tinggi di Indonesia sangat beragam, sehingga pelaksanaan program telah dirancang oleh pemerintah untuk berlangsung secara bertahap di bawah sistem berjenjang (Widanta et al.,2020; Albina \& Sumagaysay, 2020). Berdasarkan data statistik dari Dirjen Dikti, Kementerian Pendidikan dan Kebudayaan membawahi 3.169 perguruan tinggi baik negeri maupun swasta. Dari jumlah tersebut, 1.033 menyediakan pendidikan kejuruan, sedangkan 2.136 adalah lembaga pendidikan tinggi akademik, seperti universitas (Al-Mamun et al.,2020).

Program Kampus Merdeka memiliki beberapa tujuan utama, dinataranya adalah: 1) meningkatkan kualitas belajar mengajar, serta relevansi pendidikan tinggi dengan perkembangan zaman;2) meningkatkan keterampilan dosen serta tenaga kependidikan lainnya di perguruan tinggi, dan 3) mencapai kualitas manajemen yang tinggi sesuai dengan citacita Dirjen Dikti. Program ini mempromosikan empat kebijakan (Heriyadi, 2021). Pertama, kampus menjadi badan hukum otonom dengan kemampuan memperkenalkan program studi baru dengan akreditasi A dan B. Oleh karena itu, mereka dapat mengembangkan program studi baru dengan syarat berkolaborasi dengan bisnis, organisasi nirlaba, lembaga multilateral, dan/atau universitas negeri/ swasta lainnya yang masuk dalam 100QS teratas, meskipun tidak bergerak dalam bidang kesehatan dan pendidikan (Razak \& Kamaruddin, 2019). Kedua, sistem akreditasi perguruan tinggi yang merupakan proses yang sistematis atau otomatis harus dilakukan oleh perguruan tinggi setiap lima tahun sekali. Ketiga, program ini memudahkan transisi institusi dari Perguruan Tinggi Negeri (PTN) ke Badan Layanan Umum (BLU) dan akhirnya ke Badan Hukum (BH), sesuatu yang sebelumnya terbatas pada perguruan tinggi dengan akreditasi A. Keempat, program ini memberikan kesempatan kepada mahasiswa untuk belajar selama tiga semester di luar program studi mereka dengan menggeser Sistem Kredit Semester (SKS) dari pengertian "jam belajar" menjadi salah satu "jam kerja". Dengan sistem baru ini, mahasiswa dapat mengambil mata kuliah di luar program studinya hingga dua semester atau setara dengan 40 SKS (Bernie, 2020; Qorib \& Harfiani, 2021). Hal ini disebabkan pembelajaran berlangsung tidak hanya di dalam kelas, tetapi juga melalui program magang, pertukaran pelajar, kewirausahaan, penelitian, belajar mandiri, dan kegiatan mengajar ke daerah terpencil (Marisa, 2016; Hazaymeh \& Des, 2017).

Dalam rangka meningkatkan kualitas lulusan dan peningkatan kepuasan dari pengguna lulusan, Program Studi Ilmu Komunikasi Universitas Terbuka bermaksud melakukan evaluasi secara berkala terhadap kurikulum program studi dan layanan bantuan belajar. Hal ini sangat penting dilakukan sebagai sarana umpan balik antara lulusan dengan Program Studi dan mengetahui penyerapan kerja lulusan Program Studi Ilmu Komunikasi Universitas Terbuka. Dengan adanya umpan balik tersebut, diharapkan dapat dikembangkan ke arah yang lebih baik, tepat dan sesuai dengan kebutuhan dunia kerja saat ini (Hartini et al.,2017; Reusia et al.,2020).

Studi pelacakan lulusan (tracer study) di tingkat Program Studi Ilmu Komunikasi setidaktidaknya dapat memberikan informasi tentang profil kompetensi lulusan dan pengguna lulusan, baik dari perusahaan maupun instansi (Safi'I \& Priyantoro, 2019; Hafiz, 2020). Dengan demikian, diharapkan dapat menciptakan link and match secara profesional antara Perguruan Tinggi dan perusahaan/ instansi terkait secara komprehensif dan dinamis. Selain itu, hasil ini diharapkan dapat menjadi bahan evaluasi dalam pengembangan Program Studi Ilmu Komunikasi Universitas Terbuka ke depan.

Sebagai bagian integral yang berpengaruh terhadap kualitas pendidikan serta citra kampus. Hal ini sangat perlu dikembangkan meningkat banyak perguruan tinggi yang minim dalam mencari integralisasi kurikulum dengan perkembangan zaman, maka perlu ada kajian untuk menguji kualitas lulusan yang telah dihasilkan (Belecina \& Oscampo, 2017). Hal ini menjadi informasi yang penting guna menjadi evaluasi terhadap kurikulum yang ada dalam sebuah lembaga pendidikan.

Tujuan dari pelacakan lulusan ini adalah (1) mengidentifikasi profil lulusan Program Studi Ilmu Komunikasi Universitas Terbuka; (2) mengkaji penilaian layanan UT dan pengalaman belajar terkait layanan Universitas Terbuka; (3) mengkaji kompetensi yang dikuasai dan dibutuhkan oleh masyarakat 
pengguna lulusan/dunia kerja, dan (4) mengetahui keterkaitan Lulusan dengan Ikatan Alumni. Selain itu, manfaat penelitian ini terdapat tiga. Pertama, bagi Program Studi adalah sebagai bahan evaluasi diri, khususnya dalam menghasilkan lulusan; sarana untuk menciptakan atmosfir akademik yang kondusif dalam proses belajar mengajar melalui perbaikan secara terus menerus; dan evaluasi layanan yang sesuai dengan kebutuhan dunia kerja, baik untuk kepentingan pengembangan ilmu, pembangunan dan hal relevan lainnya (Andari et al.,2021; Fenta et al.,2019). Kedua, bagi lulusan adalah sebagai sarana komunikasi untuk memberikan umpan balik dalam pengembangan program studi, baik kurikulum dan relasi publik; mengetahui kekuatan dan kelemahan beserta peluang dan ancaman Program Studi Ilmu Komunikasi Universitas Terbuka dalam mengembangkan dan membina alumni; dan media katalisator dalam penyusunan informasi bursa tenaga kerja bagi calon lulusan maupun yang telah lulus, tetapi belum mendapatkan kesempatan kerja (Min-Allah \& Alrashed, 2020; Munro \& Senekal, 2019). Ketiga, bagi pengguna lulusan adalah sebagai sarana informasi dan komunikasi, serta patok duga tentang profil kompetensi lulusan Program Studi Ilmu Komunikasi Universitas Terbuka; menjalin link and match antara perguruan tinggi dengan instansi, baik swasta maupun pemerintah; dan memberikan masukan terhadap Program Studi Ilmu Komunikasi Universitas Terbuka tentang perlunya perbaikan maupun peningkatan muatan layanan yang sesuai dengan kebutuhan dunia kerja yang selalu berkembang dan maju, serta kontribusi dalam pemberdayaan dan pengembangan pembangunan masyarakat. Selain itu, sasaran dari penelitian ini adalah lulusan Program Studi Ilmu Komunikasi Universitas Terbuka dan pengguna lulusan Program Studi Ilmu Komunikasi Universitas Terbuka.

\section{METODE}

Tahapan studi merupakan langkah-langkah atau proses yang dilakukan dalam studi ini. Pada prinsipnya, studi yang dilakukan merupakan suatu proses yang diawali dengan pengumpulan berbagai data lulusan dan selanjutnya dilakukan studi empiris di lapangan, serta dilakukan analisis yang merupakan hasil studi empiris di lapangan/survai (Rosmawati \& Donal, 2017). Tahapan studi ini terdiri atas: 1) Pra studi; 2) Tahap ini terdiri dari indentifikasi lulusan Program Studi Ilmu Komunikasi Universitas Terbuka, yaitu mengumpulkan data lulusan tahun 2018. Responden lulusan berasal dari sebelas UPBJJ-
UT, yaitu Surakarta, Jakarta, Mataram, Banda Aceh, Malang, Yogyakarta, Bandung, Purwokerto, dan Bogor; 3) Pengumpulan dan pengolahan data; 4) Pada tahap ini dilakukan survai ke lapangan yang terdiri atas penyebaran kuesioner, wawancara maupun kombinasi keduanya. Selanjutnya dilakukan pengolahan data dengan menggunakan software Excel dan SPSS; 5) Analisis data; 6) Kesimpulan dan saran; dan 7) Rekomendasi berupa perbaikan, peningkatan, maupun pemantapan untuk Program Studi Ilmu Komunikasi UT.

Rancangan pengumpulan data dilakukan untuk mengetahui hal-hal yang harus dilakukan sebelum survai ke lapangan, mencakup identifikasi kebutuhan data, pemilihan teknik analisis dan metode pengumpulan data studi. Metode pengumpulan data berupa survai lapangan, wawancara, kuesioner dan kombinasi ketiganya (Aristi, 2019; Sucipto et al.,2020). Selain itu, karakteristik suatu populasi diketahui dengan pengambilan contoh melalui pengamatan untuk memberikan data dan informasi. Pada studi ini, metode penarikan contoh merupakan kombinasi dari pemilihan contoh populasi secara acak (probability sampling) yang dilanjutkkan dengan pemilihan contoh dari populasi secara tidak acak (nonprobability sampling) berupa purposive sampling. Menurut Sugiyono (2013), metode purposive sampling adalah teknik pengambilan atau penentuan sampel dengan pertimbangan tertentu. Pemilihan responden ini didasarkan pada pertimbangan responden dengan kriteria dilihat dari lulusan tahun 2018.

Jenis data yang diperlukan berupa data kualitatif dan kuantitatif dengan sumber data dari (1) data primer yang diperoleh langsung dari sumber atau objek yang diteliti yang didapatkan baik dari wawancara dan pengisian kuesioner dan (2) data sekunder, yang diperoleh dari dokumen yang relevan. Pengumpulan data dilakukan melalui data primer dan data sekunder (Suking \& Arwildayanto, 2020; Wang, 2020). Data pimer adalah data yang langsung dikumpulkan dari sumber pertama yaitu kuesioner. Adapun jumlah kuesioner yang terkumpul sebanyak 93. Data sekunder merupakan data yang telah tersusun dalam bentuk dokumen-dokumen tertulis, baik buku, laporan dan bentuk cetak lainnya. Pengolahan data dilakukan dengan Excel dan SPSS dengan menggunakan analisis deskriptif (analisis frekuensi dan gambar/grafik) untuk memudahkan dalam menyajikan data dan diagram kartesius untuk mengetahui prioritas pengetahuan dan keterampilan yang dibutuhkan oleh lulusan Program Studi Ilmu Komunikasi Universitas Terbuka. 


\section{HASIL DAN PEMBAHASAN}

\section{Identitas Lulusan}

Latar belakang responden terdiri dari jenis kelamin, asal UPBJJ-UT, status pekerjaan, tempat bekerja, pendapatan per bulan dan waktu mulai mencari pekerjaan. Berdasarkan data yang diperoleh diketahui bahwa jenis kelamin alumni didominasi oleh wanita dengan persentase sebesar $62,4 \%$ dan Laki-laki 37,6\%. Dilihat berdasarkan status pekerjaan, diketahui bahwa mayoritas lulusan program studi ilmu komunikasi sudah bekerja dengan persentase 96,8\% dan sisanya belum bekerja. Berdasarkan tempat Kerja diketahui bahwa lulusan Program Studi Ilmu Komunikasi UT yang sudah bekerja Sebagian besar bekerja di perusahaan Swasta sebanyak 41,8\%, diikuti Instansi pemerintah $(39,6 \%)$ dan menjadi wiraswasta sebesar $18,7 \%$. Jika dilihat berdasarkan pendapatan perbulan, diketahui persentase terbesar adalah pendapatan per bulan Rp3.000.000-Rp4.000.000 dan Rp4.000.000--Rp5.000.000 dengan persentase sama yaitu sebesar 23.3\%, diikuti pendapatan Rp2.000.000Rp3.000.000 sebesar 18,9\%, lebih dari Rp.5.000.000 sebesar $17,8 \%$ dan paling kecil adalah kurang dari Rp2.000.000 dengan persentase sebesar 16,7\%. Berdasarkan data yang diperoleh, diketahui bahwa persentase terbesar waktu lulusan mulai mencari pekerjaan adalah 1-2 bulan setelah lulus dengan persentase sebesar $33 \%$, diikuti 1-2 bulan sebelum lulus sebesar 23,1\%.

Secara umum lulusan Program Studi aktif mencari lowongan pekerjaan pada $1-5$ perusahaan. Jika dilihat prosesnya perusahaan yang merespon dan melakukan wawancara Sebagian besar berjumlah 1-5 perusahaan. Hal ini menunjukkan bahwa lulusan
Program Studi Ilmu Komunikasi cukup baik secara kesempatan dalam mendapatakan pekerjaan (Tabel 3.1). Adapun cara lulusan dalam mencari pekerjaan cukup bervariasi, mulai dari rekomendasi oleh teman/kerabat, mencari melalui internet/iklan online, melalui media sosial, melalui iklan di koran/majalah, melalui penempatan kerja atau magang, melamar ke perusahaan tanpa mengetahui lowongan yang ada, menghubungi Kemenakertrans dan Ikatan Alumni UT.

Tabel 1. Proses Melamar Pekerjaan

\begin{tabular}{cccc}
\hline Jumlah & \multicolumn{3}{c}{ Proses } \\
\cline { 2 - 4 } Perusahaan & Dilamar & Merespons & Wawancara \\
\hline $1-5$ & $42,6 \%$ & $63,2 \%$ & $57,4 \%$ \\
Lebih dari 5 & $36,3 \%$ & $25,3 \%$ & $19,1 \%$ \\
Tidak ada & $28,5 \%$ & $19,0 \%$ & $23,5 \%$ \\
\hline
\end{tabular}

Pengalaman Belajar

Pada bagian pengalaman belajar ini terdapat beberapa hal yang akan dipaparkan, antara lain penilaian kualitas aspek layanan Universitas Terbuka, kompetensi yang dikuasai lulusan dan kompetensi yang diperlukan dalam pekerjaan.

\section{Penilaian Kualitas Aspek Layanan Universitas Terbuka}

Aspek-aspek kualitas layanan Universitas Terbuka yang dinilai lulusan terdiri dari 6 (enam) hal, yaitu pelayanan registrasi, kecepatan memperoleh bahan ajar (modul), pelaksanaan tutorial, pelaksanaan ujian, penyelesaian kasus nilai dan pembimbingan akademik (Van Lam, 2011; Stoller, 2012). Dalam kuesioner ini, lulusan diberikan pernyataan mengenai seberapa memuaskan aspek-aspek tersebut. Data dari

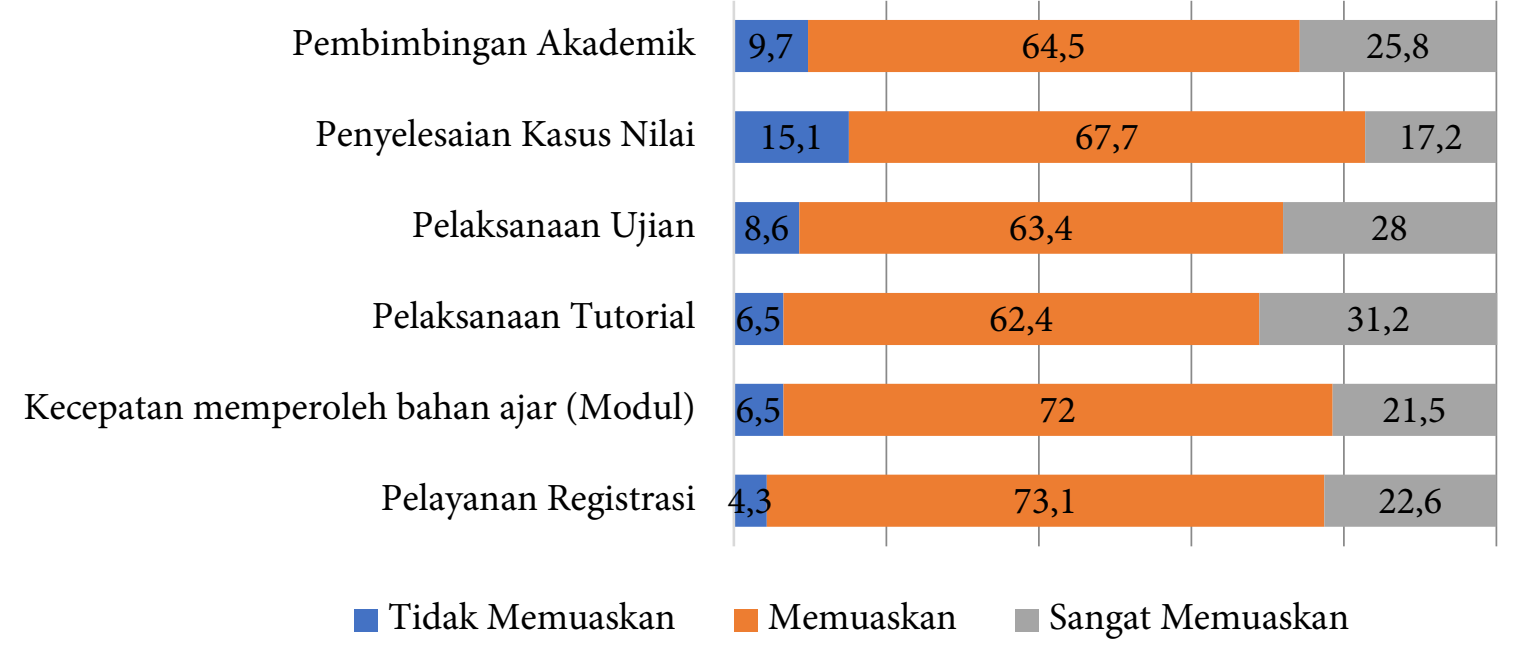

Gambar 1. Penilaian Kualitas Aspek Layanan Universitas Terbuka 
hasil jawaban kuesioner dapat dilihat dalam Gambar 1.

Berdasarkan Gambar 1, diketahui penilaian terhadap keenam aspek kualitas layanan dinilai memuaskan dan sangat memuaskan, namun jika dilihat lebih jauh masih terdapat lulusan yang menilai tidak memuaskan. Tiga besar aspek dengan persentase tidak memuaskan secara berurutan adalah aspek penyelesaian kasus nilai, pembimbingan akademik dan pelaksanaan ujian. Oleh karena itu, perlu diadakan perbaikan khususnya kepada ketiga aspek tersebut agar mutu strategi pengantaran / penyampaian dapat berjalan optimal yaitu 1). menerapkan prinsip pengajaran yang berpusat pada mahasiswa; 2). Melibatkan mahasiswa agar aktif dalam proses belajar; 3). Memberikan instruksi yang jelas dan detil (Wirastuti \& Nilakusumawati, 2020; Ozdemir et al.,2020).

\section{Penilaian Kompetensi yang Lulusan Program Studi Ilmu Komunikasi Kuasai}

Kompetensi yang dipakai dalam tracer studi ini terdiri dari 33 kompetensi. Kompetensi adalah karakteristik dasar yang dapat dihubungkan dengan peningkatan kinerja individu atau tim. Pengelompokkankompetensiterdiridaripengetahuan, keterampilan, dan kemampuan. Kompetensi sebagai pengetahuan keahlian, kemampuan atau karakteristik

Tabel 2. Tingkat Kompetensi yang Dikuasai Lulusan

\begin{tabular}{|c|c|c|c|c|}
\hline \multirow{2}{*}{ Jenis Kompetensi } & \multicolumn{4}{|c|}{ Tingkat Kompetensi yang Dikuasai } \\
\hline & Sangat Rendah & Rendah & Tinggi & Sangat Tinggi \\
\hline Pengetahuan di bidang atau disiplin ilmu Anda & 0 & 7,5 & 79,6 & 12,9 \\
\hline Pengetahuan di luar bidang atau disiplin ilmu Anda & 0 & 17,2 & 67,7 & 15,1 \\
\hline Pengetahuan umum & 0 & 5,4 & 75,3 & 19,4 \\
\hline Bahasa Inggris & 1,1 & 43 & 47,3 & 8,6 \\
\hline Keterampilan internet & 0 & 9,7 & 63,4 & 26,9 \\
\hline Keterampilan komputer & 0 & 16,1 & 63,4 & 20,4 \\
\hline Keterampilan menggunakan media sosial & 0 & 10,8 & 53,8 & 35,5 \\
\hline $\begin{array}{l}\text { Keterampilan menggunakan teknologi komunikasi dan } \\
\text { informasi }\end{array}$ & 0 & 17,2 & 60,2 & 22,6 \\
\hline Berpikir kritis & 0 & 18,3 & 68,8 & 12,9 \\
\hline Keterampilan riset/meneliti ilmiah & 1,1 & 54,8 & 35,5 & 8,6 \\
\hline Kemampuan belajar secara mandiri & 1,1 & 11,8 & 59,1 & 28 \\
\hline Kemampuan berkomunikasi & 0 & 5,4 & 68,8 & 25,8 \\
\hline Bekerja di bawah tekanan & 2,2 & 31,2 & 52,7 & 14 \\
\hline Manajemen waktu & 1,1 & 11,8 & 64,5 & 22,6 \\
\hline Bekerja secara mandiri & 0 & 5,4 & 67,7 & 26,9 \\
\hline Bekerja dalam tim/bekerja sama dengan orang lain & 0 & 10,8 & 72 & 17,2 \\
\hline Kemampuan dalam memecahkan masalah & 0 & 12,9 & 77,4 & 9,7 \\
\hline Negosiasi & 0 & 20,4 & 61,3 & 18,3 \\
\hline Kemampuan analisis & 0 & 23,7 & 64,5 & 11,8 \\
\hline Toleransi & 0 & 5,4 & 65,6 & 29 \\
\hline Kemampuan adaptasi & 0 & 6,5 & 66,7 & 26,9 \\
\hline Loyalitas & 11,8 & 1,1 & 59,1 & 28 \\
\hline Integritas & 0 & 4,3 & 76,3 & 19,4 \\
\hline $\begin{array}{l}\text { Bekerja dengan orang yang berbeda budaya maupun } \\
\text { latarbelakang }\end{array}$ & 0 & 8,6 & 66,7 & 24,7 \\
\hline Kepemimpinan & 0 & 18,3 & 63,4 & 18,3 \\
\hline Kemampuan dalam memegang tanggung jawab & 0 & 8,6 & 68,8 & 22,6 \\
\hline Inisiatif & 10,8 & 1,1 & 65,6 & 22,6 \\
\hline Manajemen proyek/program & 0 & 20,4 & 63,4 & 16,1 \\
\hline Kemampuan untuk mempresentasikan ide/laporan & 0 & 11,8 & 67,7 & 20,4 \\
\hline Kemampuan dalam menulis laporan, memo dan dokumen & 0 & 16,1 & 63,4 & 20,4 \\
\hline Kemampuan untuk terus belajar sepanjang hayat & 0 & 6,5 & 63,4 & 30,1 \\
\hline
\end{tabular}


pribadi individu yang memengaruhi secara langsung kinerja pekerjaan (Andretta et al.,1993; Brockelman et al.,2018). Menurut Klemp (Sudarmanto 2009), secara umum lulusan menilai tinggi tingkat kompetensi yang dikuasi setelah belajar di Universitas Terbuka. Walaupun demikian, perlu ada perhatian untuk beberapa kompetensi yang dinilai rendah antara lain adalah: keterampilan riset, Bahasa Inggris, bekerja di bawah tekanan, kemampuan analisis dan negosiasi (Hwang et al.,2020; Kawasaki et al.,2021). Kelima kompetensi tersebut adalah urutan dengan jawaban rendah paling besar, oleh karena itu diharapkan pihak
Program Studi Ilmu Komunikasi Universitas Terbuka dapat memperbaiki khususnya kelima kompetensi ini. Data dari hasil jawaban kuesioner dapat dilihat dalam Tabel 2.

Berdasarkan data pada Tabel 2, dari 31 kompetensi yang dinilai lulusan jika dilihat dari persentase terbesar yang menjawab tinggi dan sangat tinggi maka diketahui bahwa lima kompetensi yang diperlukan lulusan Program Studi Ilmu Komunikasi Universitas Terbuka antara lain: Kemampuan dalam memegang tanggung jawab, Kemampuan berkomunikasi, Integritas, Bekerja dalam tim/

Tabel 3. Tingkat Kompetensi yang Diperlukan Lulusan pada Pekerjaannya

\begin{tabular}{|c|c|c|c|c|c|}
\hline \multirow[b]{2}{*}{ Jenis Kompetensi } & \multicolumn{4}{|c|}{ Tingkat Kompetensi yang Diperlukan } & \multirow[b]{2}{*}{$\mathrm{T}+\mathrm{ST}$} \\
\hline & $\begin{array}{l}\text { Sangat } \\
\text { Rendah }\end{array}$ & Rendah & Tinggi & $\begin{array}{l}\text { Sangat } \\
\text { Tinggi }\end{array}$ & \\
\hline Pengetahuan di bidang atau disiplin ilmu Anda & 2,2 & 9,7 & 68,8 & 19,4 & 88,2 \\
\hline Pengetahuan di luar bidang atau disiplin ilmu Anda & 0 & 4,3 & 69,9 & 25,8 & 95,7 \\
\hline Pengetahuan umum & 0 & 7,5 & 68,8 & 23,7 & 92,5 \\
\hline Bahasa Inggris & 0 & 25,8 & 49,5 & 24,7 & 74,2 \\
\hline Keterampilan internet & 0 & 12,9 & 58,1 & 29 & 87,1 \\
\hline Keterampilan komputer & 1,1 & 11,8 & 55,9 & 31,2 & 87,1 \\
\hline Keterampilan menggunakan media sosial & 0 & 5,4 & 61,3 & 33,3 & 94,6 \\
\hline $\begin{array}{l}\text { Keterampilan menggunakan teknologi komunikasi } \\
\text { dan informasi }\end{array}$ & 0 & 14 & 55,9 & 30,1 & 86 \\
\hline Berpikir kritis & 1,1 & 10,8 & 71 & 17,2 & 88,2 \\
\hline Keterampilan riset/meneliti ilmiah & 0 & 34,4 & 53,8 & 11,8 & 65,6 \\
\hline Kemampuan belajar secara mandiri & 0 & 6,5 & 65,6 & 28 & 93,6 \\
\hline Kemampuan berkomunikasi & 0 & 2,2 & 61,3 & 36,6 & 97,9 \\
\hline Bekerja di bawah tekanan & 3,2 & 19,4 & 57 & 20,4 & 77,4 \\
\hline Manajemen waktu & 0 & 7,5 & 62,4 & 30,1 & 92,5 \\
\hline Bekerja secara mandiri & 1,1 & 5,4 & 62,4 & 31,2 & 93,6 \\
\hline Bekerja dalam tim/bekerja sama dengan orang lain & 1,1 & 2,2 & 69,9 & 26,9 & 96,8 \\
\hline Kemampuan dalam memecahkan masalah & 0 & 6,5 & 75,3 & 18,3 & 93,6 \\
\hline Negosiasi & 1,1 & 9,7 & 66,7 & 22,6 & 89,3 \\
\hline Kemampuan analisis & 1,1 & 14 & 65,6 & 19,4 & 85 \\
\hline Toleransi & 1,1 & 8,6 & 52,7 & 37,6 & 90,3 \\
\hline Kemampuan adaptasi & 0 & 7,5 & 60,2 & 32,3 & 92,5 \\
\hline Loyalitas & 0 & 6,5 & 64,5 & 29 & 93,5 \\
\hline Integritas & 0 & 3,2 & 65,6 & 31,2 & 96,8 \\
\hline $\begin{array}{l}\text { Bekerja dengan orang yang berbeda budaya maupun } \\
\text { latar belakang }\end{array}$ & 0 & 4,3 & 69,9 & 25,8 & 95,7 \\
\hline Kepemimpinan & 0 & 12,9 & 71 & 16,1 & 87,1 \\
\hline Kemampuan dalam memegang tanggung jawab & 0 & 2,2 & 66,7 & 31,2 & 97,9 \\
\hline Inisiatif & 0 & 6,5 & 65,6 & 28 & 93,6 \\
\hline Manajemen proyek/program & 0 & 15,1 & 67,7 & 17,2 & 84,9 \\
\hline Kemampuan untuk mempresentasikan ide/laporan & 1,1 & 8,6 & 61,3 & 29 & 90,3 \\
\hline $\begin{array}{l}\text { Kemampuan dalam menulis laporan, memo, dan } \\
\text { dokumen }\end{array}$ & 0 & 16,1 & 59,1 & 24,7 & 83,8 \\
\hline Kemampuan untuk terus belajar sepanjang hayat & 1,1 & 4,3 & 61,3 & 33,3 & 94,6 \\
\hline
\end{tabular}

Sumber: data diolah 


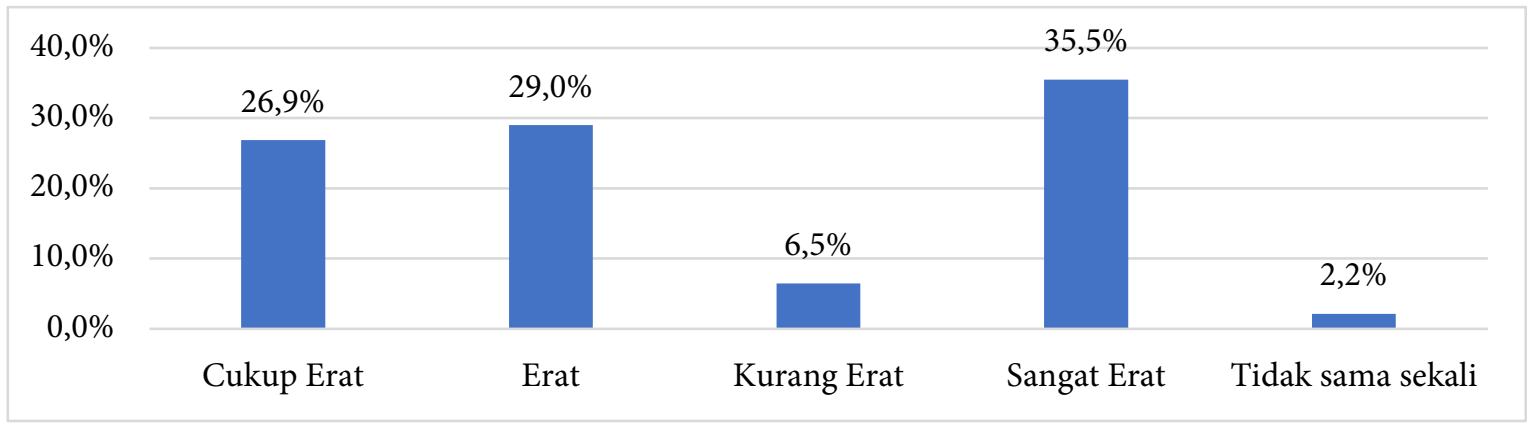

Gambar 2. Persentase jawaban lulusan terkait keeratan bidang ilmu dengan pekerjaan

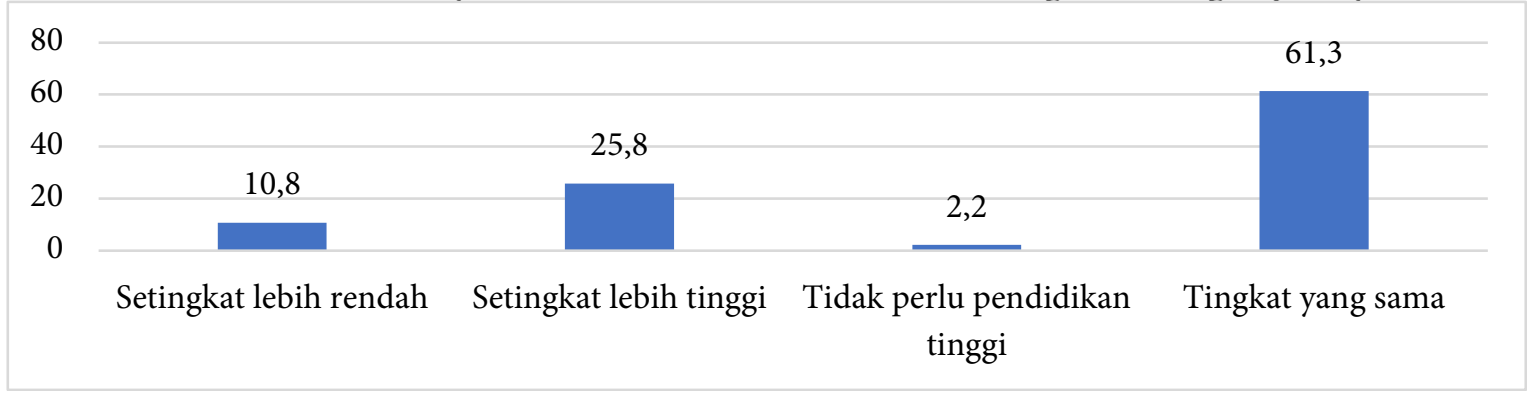

Gambar 3. Persentase Keseuaian Pendidikan dengan Tingkat Pekerjaan

bekerja sama dengan orang lain dan Pengetahuan di luar bidang atau disiplin ilmu. Berdasarkan kelima hal tersebut, sudah sepatutnya menjadi perhatian bagi Program Studi Ilmu Komunikasi Universitas Terbuka untuk membuat program pembelajaran yang dapat meningkatkan kelima kompetensi tersebut. Hal ini sesuai dengan visi Universitas Terbuka, yaitu menyediakan akses pendidikan tinggi yang berkualitas dunia bagi semua lapisan masyarakat melalui penyelenggaraan berbagai program PTTJJ untuk menghasilkan lulusan yang berdaya saing tinggi (https://www.ut.ac.id/tentang-ut).

Jika dilihat keeratan hubngan antara bidang studi dengan pekerjaan, sebagian besar menjawab sangat erat dan erat, sedangkan yang menjawab kurang erat dan tidak erat sama sekali hanya sebesar $6,5 \%$ dan 2,2\%. Hal ini menunjukkan bahwa lulusan program studi ilmu komunikasi mayoritas bekerja sesuai dengan bidang ilmunya. Dilihat dari tingkatan kerjaanya, lulusan menjawab bahwa pekerjaan yang dilakukan merupakan pekerjaan untuk tingkat Pendidikan setara yaitu Sarjana, sedangkan yang menjawab pekerjaannya lebih rendah dari sarjana sebesar 10,8\%. Lebih jelas dapat dilihat pada Gambar 2 dan 3.

\section{Ikatan Alumni}

Ketika ditanyakan berhubungan dengan Ikatan alumni, diketahui 54,8\% terdaftar Ikatan Alumni, sedangkan $45,2 \%$ tidak terdaftar atau tidak berhubungan dengan dengan ikatan Alumni Universitas Terbuka. Lebih jelas mengenai persentase lulusan berdasarkan terdaftar pada Ikatan Alumni UT dapat dilihat pada Gambar 4. Kegiatan yang dilaksanakan oleh Ikatan Alumni antara lain adalah seminar pelatihan seperti pelatihan wirausaha, hidroponik, membatik selain itu dilakukan juga bakti social seperti bantuan korban bencana alam, bagi-bagi masker dan kurban.

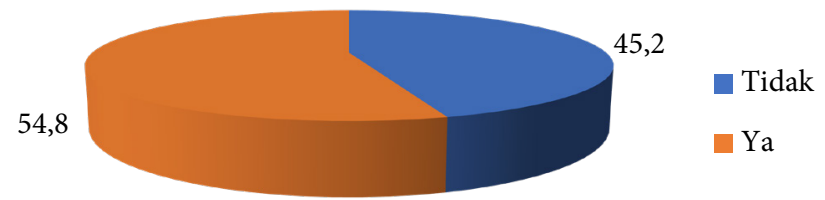

Gambar 4. Persentase Lulusan Berdasarkan Terdaftar IKA-UT

Adapun alasan lulusan tidak berpartisipasi pada Ikatan Alumni UT mayoritas menjawab dikarenakan keterbatasan waktu sebesar 62,6\%, diikuti tidak mengetahui kegiatan yang dilakukan oleh IKA-UT sebesar 22\%, lokasi rumah dengan kegiatan jauh $(6,6 \%)$, dan keterbatasan sarana (5,5\%). Lebih jelas mengenai Persentase lulusan berdasarkan alasan tidak berpartisipasi IKA UT dapat dilihat pada Gambar 5.

Berdasarkan frekuensi berkomunikasi antar sesama Alumni UT, diketahui bahwa persentase paling besar tidak pernah melakukan komunikasi pasca lulus dari Universitas Terbuka (29,\%), diikuti 3 sampai dengan 6 bulan sekali sebesar 16,1\%, 1 


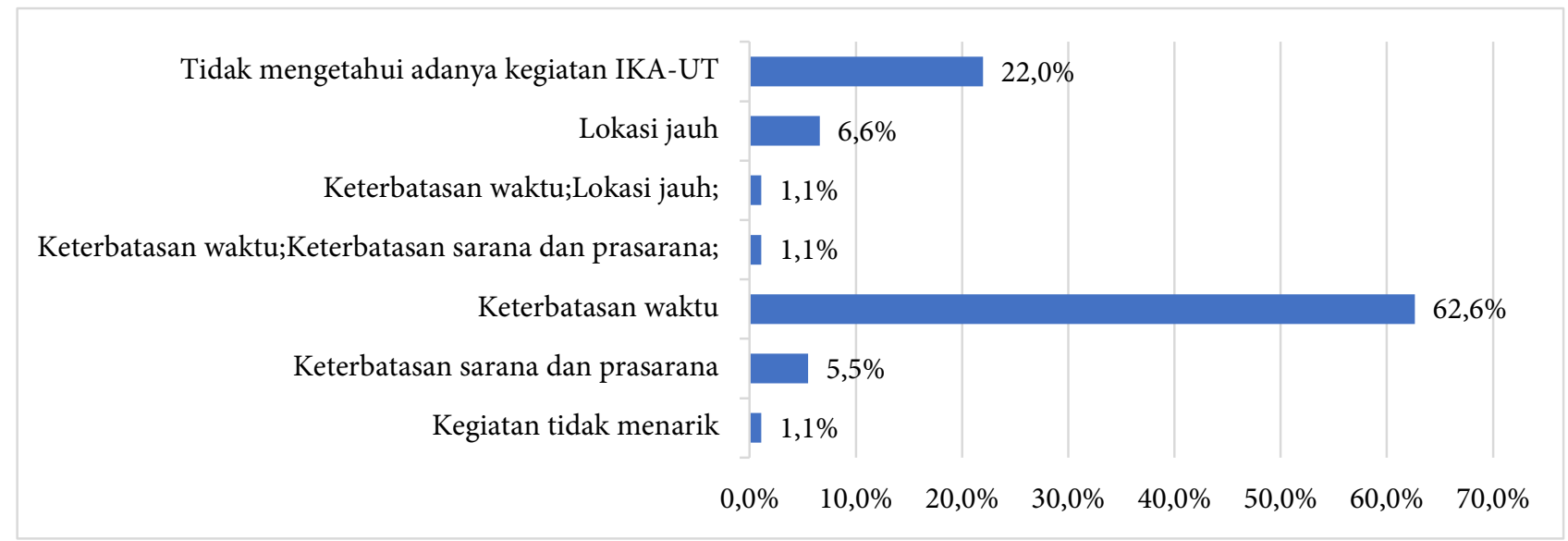

Gambar 5. Persentase Lulusan Berdasarkan Alasan tidak berpartisipasi IKA UT

sampai dengan 3 bulan sekali sebesar 14\%. Frekuensi komunikasi intens yaitu setiap hari dan setiap minggu hanya dilakukan oleh $8,6 \%$ dan 5,4\% lulusan. Media komunikasi yang paling banyak digunakan untuk berkomunikasi sesamealumni secara berurutan adalah jejaring social ((WhatsApp/Facebook/Instagram/
Twitter, dll), tatap muka (6,6\%), telpon $(4,4 \%)$ dan SMS (1,1\%). Lebih jelas mengenai Persentase lulusan Lulusan Berdasarkan Frekuensi Komunikasi Sesama Alumni dapat dilihat pada Gambar 6, sedangkan persentase media komunikasi yang digunakan dapat dilihat pada Gambar 7.

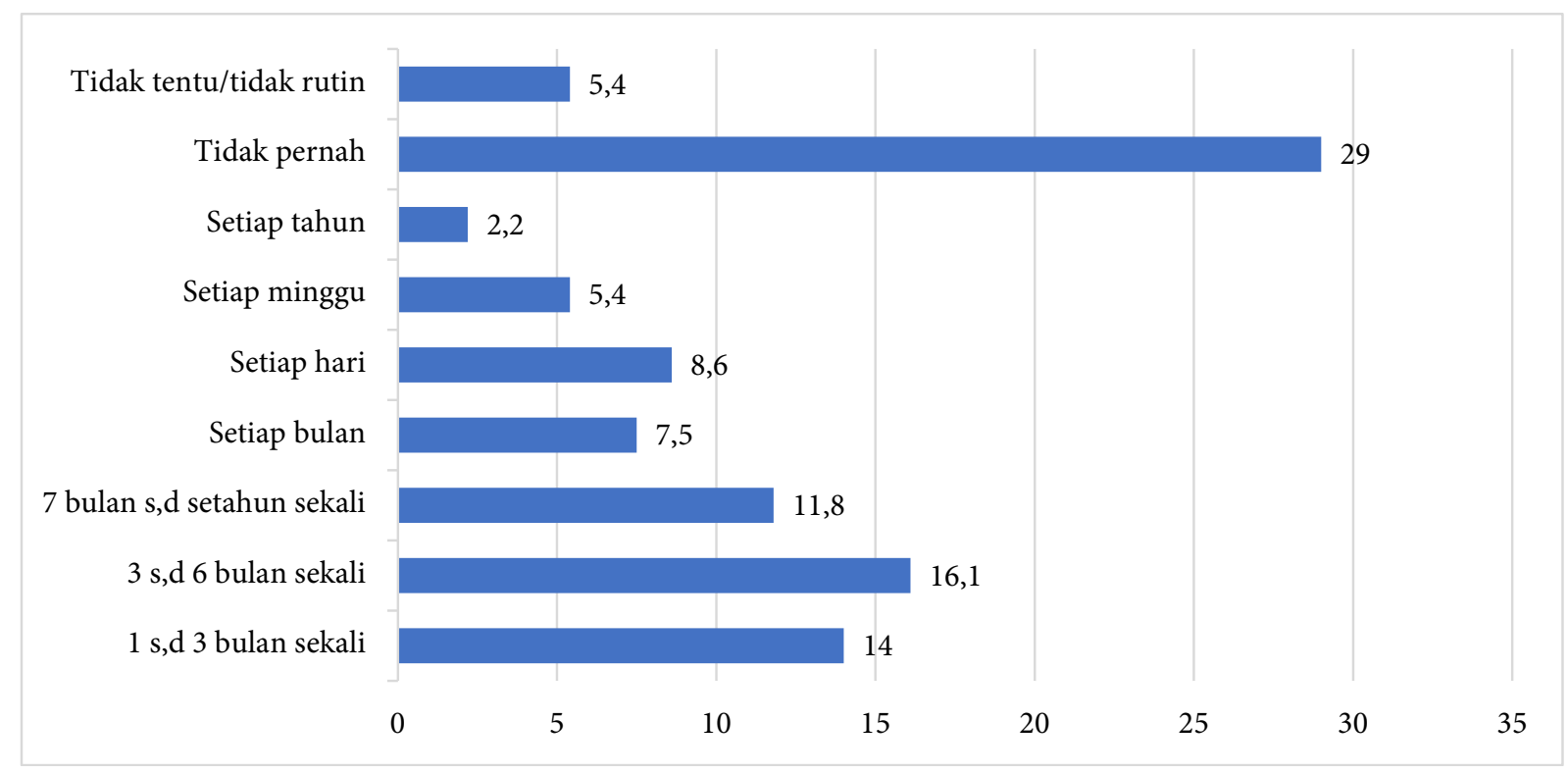

Gambar 6. Persentase Lulusan Berdasarkan Frekuensi Komunikasi Sesama Alumni

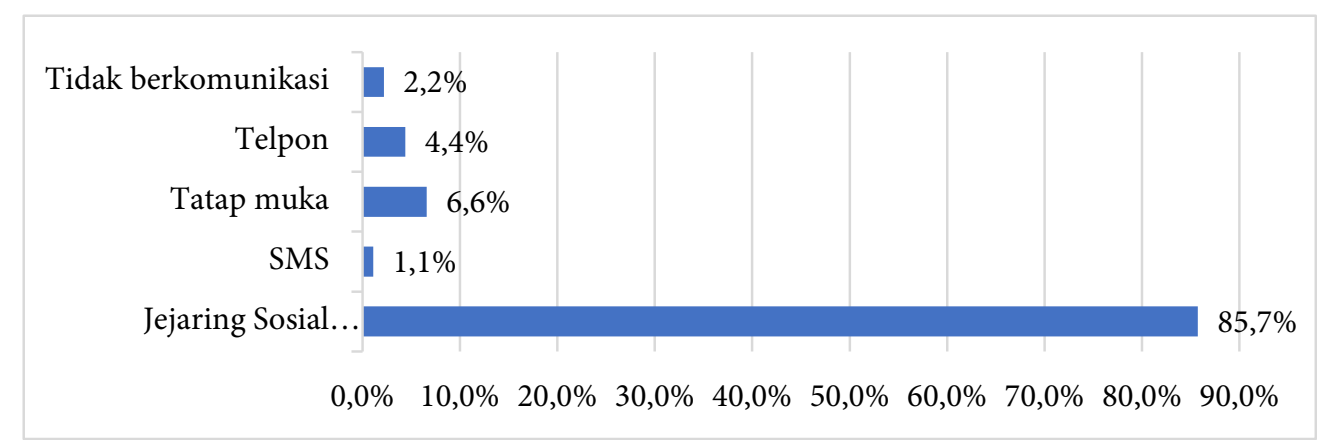

Gambar 7. Persentase Lulusan Berdasarkan Media Komunikasi yang Digunakan 


\section{Pengguna Lulusan (User)}

Para pengguna lulusan terdiri dari perusahaan dan instansi pemerintah dari berbagai bidang pekerjaan. Perusahaan yang menjadi responden adalah BNI, BRI, PT Tirta Utama Abadi, PT Renjani Royal Cosmetic, 95,1 CNL FM, PT Dexa Medica, PT Raya Sejahtera, PT Lien Industri, PT Telkom, PT KAI DAOP 5, Badan Pemberdayaan Masyarakat, Perempuan dan Keluarga Berencana (BPMPKB), Dinas Pengendalian Penduduk dan Keluarga Berencana, Pemberdayaan Perempuan dan Perlindungan Anak (DPPKBP2PA), PT KAI, dll.

Secara umum penilaian pengguna lulusan terkait dengan kinerja lulusan UT jika dibandingkan dengan perguruan tinggi lain adalah setara dengan

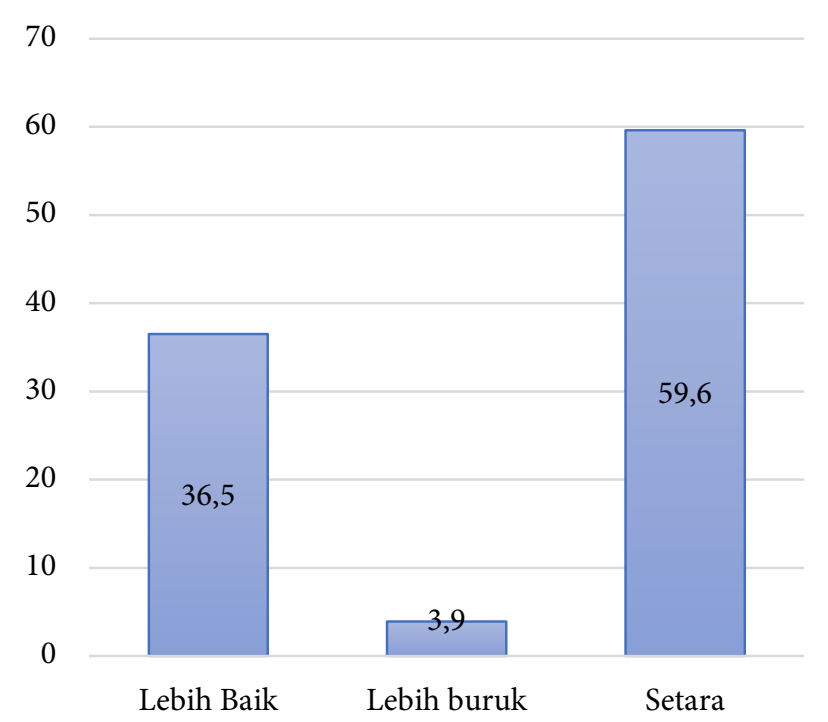

Gambar 8. Persentase Kinerja Lulusan UT disbanding Perguruan Tinggi Lain persentase sebesar 59,6\%, diikuti lebih baik sebesar $36,5 \%$ dan lebih buruk sebesar 3,9\%. Hal ini menunjukkan bahwa dalam dunia kerja, lulusan UT dapat bersaing dengan lulusan dari perguruan tinggi tatap muka lainnya. Lebih jelas dapat dilihat pada Gambar 8.

Pengguna menilai lulusan berdasarkan 31 aspek kompetensi yang dimiliki lulusan program studi ilmu komunikasi Universitas Terbuka dengan pilihan jawaban menggunakan empat tingkatan mulai dari sangat rendah, rendah, tinggi, dan sangat tinggi. Hasil dari penilaian pengguna lulusan berdasarkan jenis kemampuan dapat dilihat pada Gambar 9.

Berdasarkan hasil yang didapat dari pengguna lulusan pada Gambar 9, diketahui secara umum penilaian pengguna adalah tinggi. Jika diurutkan berdasarkan penilaian tinggi dan sangat tinggi, sepuluh aspek kompetensi yang dinilai baik dan merupakan keunggulan dari lulusan program studi ilmu komunikasi Universitas Terbuka secara berurutan adalah aspek pengetahuan di bidang atau disiplin ilmu dari lulusan, bekerja dalam tim/ bekerja sama dengan orang lain, pengetahuan umum, kemampuan adaptasi, loyalitas, pengetahuan diluar bidang, kemampuan berkomunikasi, kemampuan dalam memecahkan masalah, bekerja dengan orang yang berbeda budaya/latar belakang, bekerja di bawah tekanan. Sepuluh Aspek Kompentensi dengan Penilaian Tinggi dan Sangat Tinggi Terbesar dapat dilihat pada Tabel 4.

Jika diurutkan berdasarkan jawaban rendah dan sangat rendah, diketahui 10 aspek yang harus menjadi pertimbangan program studi ilmu komunikasi UT dalam mengembangkan kompetensi antara lain aspek kemampuan belajar, Bahasa Inggris,

Tabel 4. Sepuluh Aspek Kompentensi dengan Penilaian Tinggi dan Sangat Tinggi Terbesar

\begin{tabular}{clc}
\hline Urutan & \multicolumn{1}{c}{ Aspek Kompetensi } & $\begin{array}{c}\text { Persentase Penilaian } \\
\text { Sangat Tinggi dan Tinggi }\end{array}$ \\
\hline 1 & Pengetahuan di bidang atau disiplin ilmu dari Lulusan & 100 \\
2 & Bekerja dalam tim/bekerja sama dengan orang lain & 98,1 \\
3 & Pengetahuan umum & 98,1 \\
4 & Kemampuan adaptasi & 98,1 \\
5 & Loyalitas & 98 \\
6 & Pengetahuan di luar bidang atau disiplin ilmu dari Lulusan & 96,2 \\
7 & Kemampuan berkomunikasi & 96,2 \\
8 & Kemampuan dalam memecahkan masalah & 96,2 \\
9 & Bekerja dengan orang yang berbeda budaya maupun & \\
& latarbelakang & 96,2 \\
\hline
\end{tabular}

Sumber: data diolah 
Ida Royandiah dkk, TitleKajian Penyempurnaan Kurikulum Program Studi Ilmu Komunikasi Universitas ...

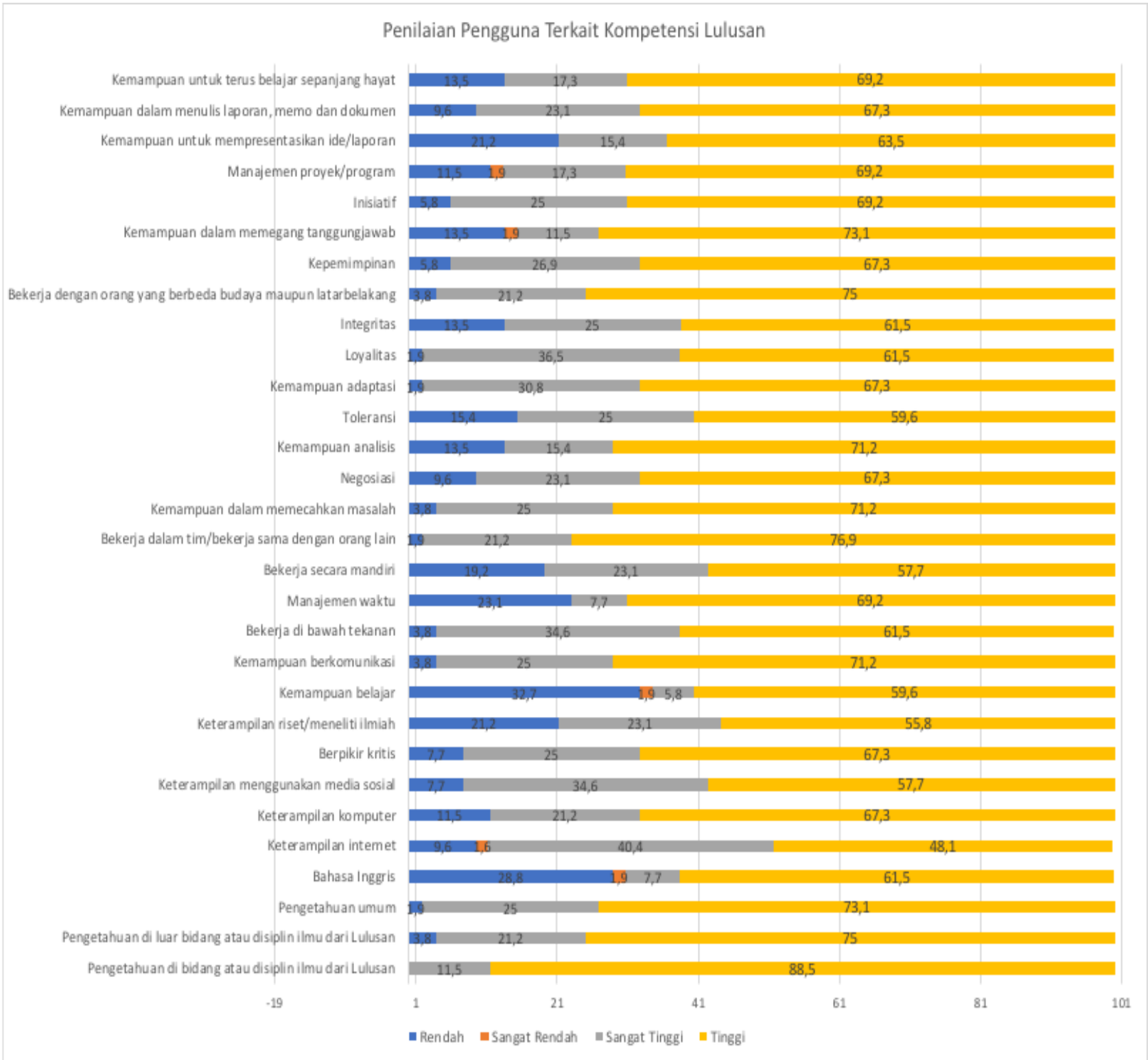

Gambar 9. Penilaian Pengguna Lulusan Berdasarkan Kompetensi

manajemen waktu, Keterampilan riset/meneliti ilmiah, Kemampuan untuk mempresentasikan ide/laporan, Bekerja secara mandiri, toleransi, Kemampuan dalam memegang tanggungjawab, Kemampuan analisis dan integritas. Kompetensi yang dimiliki lulusan prodi Ilmu Komunikasi sesuai dengan pengembangan tenaga kerja yaitu mengenali dan merespons perubahan dinamis yang terjadi di tempat kerja saat ini dapat membuat transisi yang efektif ke dunia kerja. Jelas bahwa keberhasilan kita dalam membangun tenaga kerja yang berdaya saing global bergantung pada kemampuan sistem pengembangan tenaga kerja kita untuk memberikan keterampilan kelayakan kerja, baik keterampilan akademik dasar (menulis, mendengarkan, berbicara) maupun kompetensi tingkat tinggi yang dibutuhkan untuk sukses di tempat kerja saat ini (Bates, Reid \& Phelan, Kelli, 2002). Sepuluh Aspek Kompentensi dengan Penilaian Rendah dan Sangat Rendah Terbesar dapat dilihat pada Tabel 5.

Pengguna lulusan juga ditanyakan terkait dengan bidang Kerja Sama yang dapat dilakukan antara Universitas Terbuka dengan instansi/lembaga tempat bekerja. Berdasarkan hasil jawaban pengguna, diketahui bahwa bidang Kerja Sama dengan persentase jawaban tertarik dan sangat tertarik terbesar adalah perkuliahan dengan persentase sebesar $78,8 \%$, diikuti program training $(77 \%)$, pengembangan kurikulum (76,9\%), pembelajaran online (75\%), magang $(73,1 \%)$, program beasiswa $(71,1 \%)$ dan karya wisata $(67,3 \%)$. Lebih jelas dapat dilihat pada Gambar 10 berikut: 
IKOMIK: Jurnal Ilmu Komunikasi dan Informasi 1(2) 2021 102-115

Tabel 5. Sepuluh Aspek Kompentensi dengan Penilaian Rendah dan Sangat Rendah Terbesar

\begin{tabular}{clc}
\hline Urutan & \multicolumn{1}{c}{ Aspek Kompetensi } & $\begin{array}{c}\text { Persentase Penilaian Sangat } \\
\text { Rendah dan Rendah }\end{array}$ \\
\hline 1 & Kemampuan belajar & 34,6 \\
2 & Bahasa Inggris & 30,7 \\
3 & Manajemen waktu & 23,1 \\
4 & Keterampilan riset/meneliti ilmiah & 21,2 \\
5 & Kemampuan untuk mempresentasikan ide & 21,2 \\
6 & Bekerja secara mandiri & 19,2 \\
7 & Toleransi & 15,4 \\
8 & Kemampuan dalam memegang tanggungjawab & 15,4 \\
9 & Kemampuan analisis & 13,5 \\
10 & Integritas & 13,5 \\
\hline
\end{tabular}

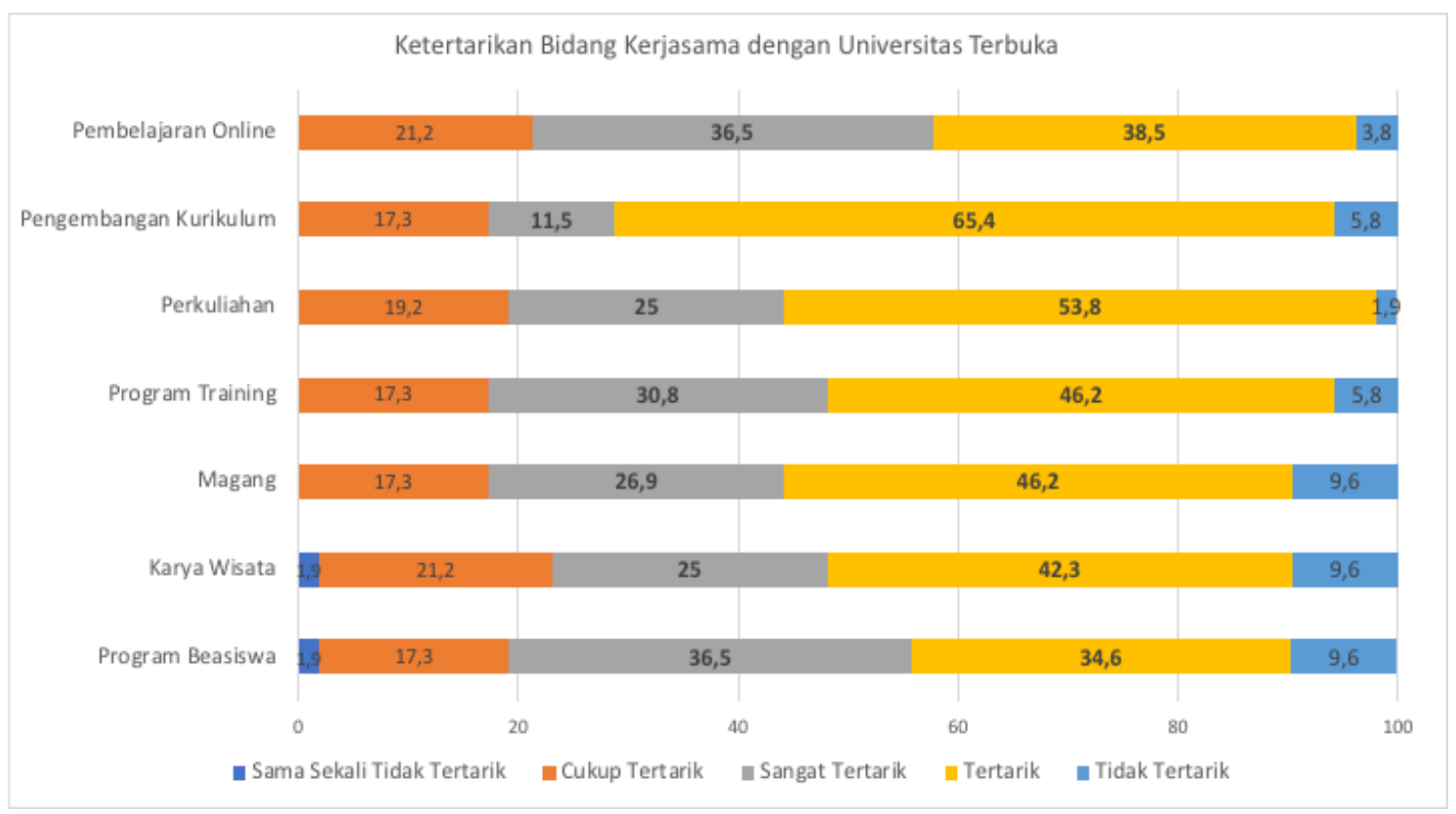

Gambar 10. Bidang Kerjasama UT dengan Instansi/Lembaga Pengguna

Dari hasil wawancara dengan beberapa pengguna diperoleh saran peningkatan kompetensi lulusan Program Studi Ilmu Komunikasi Universitas Terbuka dalam hal berikut ini:

- Praktik dalam bidang ilmu komunikasi, khususnya public speaking dan teknik menulis berita

- Kemampuan Bahasa Inggris

- Cara mengatasi complain (handling complain)

- Kemampuan manajemen dan teknologi informasi

Terkait dengan kemampuan public speaking dari hasil wawancara dengan beberapa pengguna diperoleh informasi bahwa kemampuan alumni UT untuk public speaking masih kurang dibandingkan alumni dari perguruan tinggi lain. Oleh karena itu, mereka memberi saran agar UT bisa meningkatkan kemampuan public speaking pada mahasiswanya. Pendapat yang dikemukakan pengguna bisa dimengerti mengingat saat ini mata kuliah Public Speaking masih diberikan secara teoritis oleh program studi dan belum dilengkapi dengan praktik sebagaimana yang biasanya diberikan pada perguruan tinggi tatap muka (Nunes et al.,2018; Morano \& Tzouanas, 2017). Sistem belajar jarak jauh menjadi kendala untuk melaksanakan kegiatan praktik secara langsung untuk mahasiswa (Kawasaki et al.,2021; McCLuskey et al.,2019). Namun, dengan kemajuan 
teknologi dan informasi bisa menjadi pertimbangan dan alternatif bagi program studi untuk mendesain model praktik untuk mata kuliah yang sifatnya praktis, seperti public speaking.

Tidak berbeda dengan Public Speaking, untuk teknik menulis berita juga menjadi masukan bagi program studi karena menurut pengguna yang lingkup kerjanya bergerak dalam bidang media, kemampuan alumni dalam menulis berita masih kurang sehingga mereka memberi masukan agar UT meningkatkan kompetensi mahasiswanya dalam bidang menulis berita. Pada Program Studi S1 Ilmu komunikasi FHISIP UT, kompetensi ini seharusnya bisa diperoleh mahasiswa melalui matakuliah Teknik Mencari dan Menulis Berita.

Dua kompetensi yang disarankan peningatanya oleh pengguna tersebut, yaitu Public Speaking dan Teknik Mencari dan Menulis Berita adalah mata kuliah yang menjadi ciri khas dari Program Studi Ilmu Komunikasi yang membedakan dengan Program Studi lain sehingga masukan dari pegguna harus benar-benar menjadi perhatian dan bisa diakomodasi oleh Program Studi S1 Ilmu Komunikasi FHISIP UT.

\section{SIMPULAN}

Ada enam kesimpulan yang diperoleh dari penelitian ini. (1) Profil lulusan program studi ilmu komunikasi Universitas Terbuka didominasi wanita, sudah bekerja sebesar, paling banyak bekerja di perusahaan swasta, dengan pendapatan Rp.3.000.000-Rp.5.000.000. (2) Penilaian terhadap aspek kualitas layanan secara umum dinilai memuaskan dan sangat memuaskan, tetapi perlu ditingkatkan terkait dengan aspek penyelesaian kasus nilai, pembimbingan akademik dan pelaksanaan ujian. (3) Secara umum lulusan menilai tinggi tingkat kompetensi yang dikuasi setelah belajar di Universitas Terbuka. Aspek yang perlu diperhatikan antara lain: keterampilan riset, Bahasa Inggris, bekerja di bawah tekanan, kemampuan analisis dan negosiasi. Lima kompetensi yang diperlukan lulusan Program Studi Ilmu Komunikasi Universitas Terbuka antara lain: Kemampuan dalam memegang tanggung jawab, Kemampuan berkomunikasi, Integritas, Bekerja dalam tim/bekerja sama dengan orang lain dan Pengetahuan di luar bidang atau disiplin ilmu. (4) Keterkaitan dengan Ikatan Alumni diketahui 54,8\% terdaftar Ikatan Alumni UT, dengan frekuensi komunikasi 3-6 bulan sekali. Hambatan mengikuti kegiatan Alumni adalah keterbatasan waktu. (5) Pengguna lulusan menilai kinerja lulusan UT setara dibandingkan dengan perguruan tinggi lain. Sepuluh aspek kompentesi yang dinilai tinggi dan sangat tinggi adalah pengetahuan di bidang atau disiplin ilmu dari lulusan, bekerja dalam tim/bekerja sama dengan orang lain, pengetahuan umum, kemampuan adaptasi, loyalitas, pengetahuan diluar bidang, kemampuan berkomunikasi, kemampuan dalam memecahkan masalah, bekerja dengan orang yang berbeda budaya/ latar belakang, bekerja dibawah tekanan. (6) Adapun kekurang yang ada pada alumni UT menurut pengguna adalah dalam hal praktik public speaking, praktik menulis berita, Bahasa Inggris, cara mengatasi keluhan, manajemen dan Teknologi Informasi

Saran untuk peningkatan pembelajaran mahasiswa adalah sebagai berikut. (A) Meningkatkan praktik khususnya public speaking dan Teknik Mencari dan Menulis Berita; (B) Meningkatkan kemampuan bahasa Inggris, (C) Meningkatkan cara mengatasi keluhan; (D) Meningkatkan kemampuan manajemen dan Teknologi Informasi. Saran untuk hubungan dosen-mahasiswa-alumni adalah sebagai berikut. (1) Mengadakan acara rutin untuk saling mempererat hubungan dosen-mahasiswa-alumni seperti reuni, acara buka puasa bersama, kegiatan lomba dan lainlain; (B) Melibatkan alumni dalam acara kampus baik bersifat sharing pengalaman ataupun praktik dunia kerja; (C) Menjaga silahturahmi dan komunikasi. (D) Kerja sama antara instansi pengguna dan Universitas Terbuka meliputi pelatihan pengembangan kurikulum, pembelajaran online, dan program beasiswa.

\section{DAFTAR PUSTAKA}

Al Mamun, M. A., Lawrie, G., \& Wright, T. (2020). Instructional design of scaffolded online learning modules for self-directed and inquiry-based learning environments. Computers \& Education, 144, 103695.

Albina, A. C., \& Sumagaysay, L. P. (2020). Employability tracer study of Information Technology Education graduates from a state university in the Philippines. Social Sciences \& Humanities Open, 2(1), 100055.

Andari, S., Setiawan, A. C., \& Rifqi, A. (2021). Educational Management Graduates: A Tracer Study from Universitas Negeri Surabaya, Indonesia. IJORER: International Journal of Recent Educational Research, 2(6), 671-681.

Andretta, M., Bianconi, R., Flospergher, W., \& Tamponi, M. (1993). The MRBT model: an analytical dispersion model in a finite mixing layer. Sensitivity analysis and validation against tracer measurements. Atmospheric Environment. Part A. General Topics, 27(11), 16651672.

Aristi, G. (2019, July). Implementation Business System Planning for the Design of Tracer Study at Perjuangan University. In Journal of Physics: 
Conference Series (Vol. 1179, No. 1, p. 012025). IOP Publishing.

Bates, R. A., \& Phelan, K. C. (2002). Characteristics of a Globally Competitive Workforce. Advances in Developing Human Resources, 4(2), 121-132.

Belecina, R. R., \& Ocampo Jr, J. M. (2017). Towards quality graduate mathematics teacher education: A PNU CGSTER tracer study. Sosiohumanika, 10(1), 45-56.

Broeckelman-Post, M., Hawkins, K. H., Malterud, A., Arciero, T., \& Nelson, A. (2018, August). SOTL: Campus Challenges as a Catalyst for Creative Curriculum Revision. In Innovations in Teaching \& Learning Conference Proceedings (Vol. 10).

Fenta, H. M., Asnakew, Z. S., Debele, P. K., Nigatu, S. T., \& Muhaba, A. M. (2019). Analysis of supply side factors influencing employability of new graduates: A tracer study of Bahir Dar University graduates. Journal of Teaching and Learning for Graduate Employability, 10(2), 67-85.

Fitri, I., Marisa, A., \& Sitorus, R. (2020, April). Understanding the Historic Centre of Merdeka-Kesawan: Heritage Significance Assessment in Planning and Development Context. In IOP Conference Series: Earth and Environmental Science (Vol. 452, No. 1, p. 012048). IOP Publishing.

Hafiz, A. (2020). Tracer Study Alumni Prodi Pendidikan Islam Anak Usia Dini Stain Gajah Putih Takengon. Jurnal As-Salam, 4(1), 1-12.

Hartini, S., Bhakti, C. P., \& Hartanto, D. (2017, May). A Tracer Study on the Graduates of Guidance and Counseling Department of Ahmad Dahlan University. In 1st Yogyakarta International Conference on Educational Management/Administration and Pedagogy (YICEMAP 2017).

Hazaymeh, E. N., \& Dela Peña, M. K. (2017). A tracer study of La Salle University College of Engineering graduates. Retrieved August, 18(1), 52-68.

Heriyadi, B. (2021). Tracer Study Analysis for the Reconstruction of the Mining Vocational Curriculum in the Era of Industrial Revolution 4.0. Turkish Journal of Computer and Mathematics Education (TURCOMAT), 12(3), 3013-3019.

Kardoyo, K., Nurkhin, A., \& Melati, I. S. (2018, September). A Profile of Master-Degree Program Graduates of Economic Education, UNNES: A Tracer Study. In International Conference on Science and Education and Technology.

Kawasaki, K., Kubota, Y., \& Yajima, K. (2021, April). Attempts to improve the curriculum based on ongoing research into Generic Skills. In 2021 IEEE Global Engineering Education Conference (EDUCON) (pp. 74-79). IEEE.

Khasanah, U. (2019). Tracer study as an effort to improve higher islamic education quality and relevance. ATTARBIYAH: Journal of Islamic Culture and Education, 4(2), 121-143.

Marisa, F., Efendi, D. U., \& Mumpuni, I. D. (2016,
October). Tracer Study System Portal-Based Social Network To Optimize Data Collection on Higher Education Graduates. In International Conference on Information Technology and Business (ICITB) (pp. 19-24).

McCluskey, T., Weldon, J., \& Smallridge, A. (2019). Rebuilding the first year experience, one block at a time. Student Success, 10(1), 1-16.

Min-Allah, N., \& Alrashed, S. (2020). Smart campus-A sketch. Sustainable Cities and Society, 59, 102231.

Morano, L., \& Tzouanas, V. (2017). Urban agricultural and sustainability program at Houston's downtown university: Combining new curriculum, hands-on projects, and a hurricane. Journal of Agriculture, Food Systems, and Community Development, 7(4), 23-33.

Munro, N., \& Senekal, J. (2019). Lessons learnt from two decades of graduate tracer research: Recommendations for the South African context. South African Journal of Higher Education, 33(2), 230-248.

Nunes, B. T., Pollard, S. J., Burgess, P. J., Ellis, G., De los Rios, I. C., \& Charnley, F. (2018). University contributions to the circular economy: professing the hidden curriculum. Sustainability, 10(8), 2719.

Ozdemir, Y., Kaya, S. K., \& Turhan, E. (2020). A scale to measure sustainable campus services in higher education: "Sustainable Service Quality". Journal of Cleaner Production, 245, 118839.

Putra, I. M. A., Widanta, I. R. J., Ardika, I. W. D., Hudiananingsih, P.D., Yuliantini, N.N., \& Sitawati, A. A. R. (2021, April). Designing English for Vocational Purposes (EVP) in the Context of Merdeka Belajar of Kampus Merdeka. In International Conference on Applied Science and Technology on Social Science (ICAST-SS 2020) (pp. 266-272). Atlantis Press.

Ratnaningsih, D. (2013). Open and distance education systems: do they enhance graduates' soft skills? The results from 2009 Universitas Terbuka Tracer Study. Open Praxis, 5(4), 289-299.

Razak, F., \& Kamaruddin, R. (2019). Tracer Study STKIP Alumni Andi Matappa. Global Science Education Journal, 1(2), 194-203.

Reusia, D. H. R., Danilo Jr, V. R., \& Andres, K. P. (2020). Science education graduates of a state university from 2008-2018: A tracer study. The Normal Lights, 14(1).

Rosmawati, R., \& Donal, D. (2017). Tracer study of graduate students in guidance and counseling program at the faculty of education in Universitas Riau. TERAPUTIK: Jurnal Bimbingan dan Konseling, 1(2), 113-118.

Safi'i, I., \& Priyantoro, P. (2019). Tracer Study as an Effort to Improve Alumni Careers in Kadiri University Job Placement Service. KONSELI: Jurnal Bimbingan dan Konseling (E-Journal), 6(2), 157-166.

Sihombing, A. A., Anugrahsari, S., Parlina, N., \& 
Kusumastuti, Y. S. (2021). Merdeka Belajar in an Online Learning during The Covid-19 Outbreak: Concept and Implementation. Asian Journal of University Education, 17(4), 35-48.

Stoller, F. L. (2012). Project-based learning: A viable option for second and foreign language classrooms. KOTESOL Proceedings 2012, 37.

Stroth, C., Knecht, R., Günther, A., Behrendt, T., \& Golba, M. (2018). From experiential to research-based learning: The Renewable Energy Online (REO) master's program. Solar Energy, 173, 425-428.

Sucipto, S., Dewi, E. K., Resti, N. C., \& Santi, I. H. (2020). Improving The Performance of Alumni Achievement Assessment by Integrating WebsiteBased Tracer Study Information Systems and Telegram. TEKNIK, 41(1), 72-77.

Sudarmanto. 2009. Kinerja dan Pengembangan Kompetensi SDM. Yogyakarta: Pustaka Pelajar

Sugiyono. 2013. Metode Penelitian Pendidikan Pendekatan Kuantitatif, Kualitatif, dan RéD. Bandung: Alfabeta
Suking, A., \& Arwildayanto, B. M. (2020). Strengthening The Accreditation Of Study Program Through Tracer Study. The Challenges of Educational Management And Administration in Competitive Environment, 379.

Van Lam, N. T. (2011). Project-based learning in teaching English as a foreign language. VNU Journal of Foreign Studies, 27(2).

Wang, J. J. (2020). Promoting School's Recovery and Resilience after the Chi-Chi earthquake. Disaster Prevention and Management: An International Journal.

Widanta, I. M. R. J., Hudiananingsih, P. D., Sitawati, A. A. R., \& Ardika, I. W. D. (2020). Pragmatic development in foreign learners of Indonesian. Opción: Revista de Ciencias Humanas y Sociales, (27), 116.

Wirastuti, NMAED dan Nilakusumawati DPE. 2020. Penjaminan Mutu SPADA. Diakses 5 Desember 2020. 